\title{
Postnatal oogenesis in humans: a review of recent findings
}

This article was published in the following Dove Press journal:

Stem Cells and Cloning: Advances and Applications

20 March 2015

Number of times this article has been viewed

\section{Irma Virant-Klun}

Department of Obstetrics and Gynaecology, University Medical Center Ljubljana, Ljubljana, Slovenia
Correspondence: Irma Virant-Klun Department of Obstetrics and Gynaecology, University Medical

Centre Ljubljana, Slajmerjeva 3,

1000 Ljubljana, Slovenia

Tel +386 I 5226256

Fax +386 I 5226130

Email irma.virant@kclj.si
Abstract: In spite of generally accepted dogma that the total number of follicles and oocytes is established in human ovaries during the fetal period of life rather than forming de novo in adult ovaries, some new evidence in the field challenges this understanding. Several studies have shown that different populations of stem cells, such as germinal stem cells and small round stem cells with diameters of 2 to $4 \mu \mathrm{m}$, that resembled very small embryonic-like stem cells and expressed several genes related to primordial germ cells, pluripotency, and germinal lineage are present in adult human ovaries and originate in ovarian surface epithelium. These small stem cells were pushed into the germinal direction of development and formed primitive oocyte-like cells in vitro. Moreover, oocyte-like cells were also formed in vitro from embryonic stem cells and induced pluripotent stem cells. This indicates that postnatal oogenesis is not excluded. It is further supported by the occurrence of mesenchymal stem cells that can restore the function of sterilized ovaries and lead to the formation of new follicles and oocytes in animal models. Both oogenesis in vitro and transplantation of stem cell-derived "oocytes" into the ovarian niche to direct their natural maturation represent a big challenge for reproductive biomedicine in the treatment of female infertility in the future and needs to be explored and interpreted with caution, but it is still very important for clinical practice in the field of reproductive medicine.

Keywords: human, follicle, oocyte, stem cells

\section{Introduction}

It is still generally accepted that the end number of follicles and oocytes is established in human ovaries during the fetal period of life and does not increase following birth. Nevertheless, since the early days of this field of research there have been several theoretical suggestions that, from an evolutionary point of view, de novo oogenesis is to be expected, as well as with regard to spermatogenesis, which takes place in human testicles during the adult period of life. ${ }^{1-6}$ Despite this concept, no experimental evidence existed to support it. Now, however, an increasing number of studies show that different populations of stem cells are present in adult human ovaries and the ovaries of other mammalian species. These stem cell populations may represent potential for de novo oogenesis and the capability of adult human ovaries to regenerate.

The aim of this manuscript is to critically review the present literature on the subject in order to estimate the arguments pro and contra postnatal oogenesis in humans.

\section{Introduction to oogenesis in humans}

An oocyte is a female germ cell involved in reproduction. It is one of the largest cells in the body and develops in the ovarian follicle, a specialized unit of the ovary, during the 
process of oogenesis/folliculogenesis in the cortex. ${ }^{7}$ The process of oogenesis starts in the fetal ovaries with the development of oogonia from primordial germ cells (PGCs). Each oogonium in the fetal ovaries divides and enters the initial stage of meiosis (meiosis I) to become the diploid primary oocyte. The primary oocyte does not complete meiosis I but stops at the first meiotic prophase stage, dictyate. At this stage of development the oocyte nucleus is called the germinal vesicle $(\mathrm{GV})$. GV oocytes are localized within the primordial follicles. By the end of the fetal period, all primary oocytes are formed and have halted their development at the dictyate stage. Although meiosis in primary oocytes is arrested, their chromosomes continue to synthesize amounts of mRNA and rRNA, which are later used to generate a mass of essential proteins needed for further oocyte maturation and the development of any fertilized oocytes and embryos. ${ }^{7}$ The primary oocytes are maintained for years, until puberty. Upon puberty only a few -15 to 20 - primary oocytes/follicles are recruited during each menstrual cycle, and only one oocyte in the dominant follicle matures and is ovulated. During this maturation, the primary oocyte finishes meiosis I and divides into two daughter cells: a haploid secondary oocyte and an extruded nonfunctional polar body. Meiosis does not completely finish but is arrested again at the metaphase II stage and terminates after successful fertilization by sperm when the second polar body is extruded. The primary oocytes grow and mature during the development and maturation of primordial, primary, and secondary follicles, whereas the secondary oocytes develop along with the tertiary and preovulating Graafian follicle. ${ }^{7}$ Developing oocytes are strongly supported by surrounding follicular - granulosa - cells. The process of oogenesis/folliculogenesis is highly regulated by hormones and other substances.

It is generally accepted that human ovaries contain a fixed number of non-growing follicles established before birth that decreases with female age and is depleted in menopause. ${ }^{8-17}$ Wallace and Kelsey established an age-related model of the population of non-growing follicles in human ovaries from conception to menopause based on eight separate quantitative histological studies in which non-growing follicle populations at known female ages from 7 weeks post-conception to menopause (51 years old) were estimated. ${ }^{18}$ They found that in the ovaries of $95 \%$ of women by the age of 30 years only $12 \%$ of their maximal pre-birth non-growing follicle population is present and by the age of 40 years only $3 \%$ still remains. In countable terms, at birth approximately $1,000,000$ or more follicles were regularly present in the ovaries, at age 30 generally between 10,000 and 100,000 follicles, at age 40 between 1,000 and 10,000 follicles, and at menopause the number of follicles had declined to less than 1,000 follicles. Interestingly, it was found that the rate of non-growing follicle recruitment in the ovaries of most women increased from birth until approximately the age of 14 years and then intensely decreased towards menopause. This model is supposed to be the first model of the human ovarian reserve from conception to menopause and enables one to estimate the number of non-growing follicles present in the ovaries at any given female age. In the future, it will be important to elucidate how infertility, cancer treatment (radiotherapy and chemotherapy), and environmental and other factors affect the model.

\section{Postnatal oogenesis in nonhuman mammals}

As already described, oogonia are characterized by diploidy and mitotic proliferation. In addition, human and mouse oogonia express several factors which are characteristic of pluripotent stem cells, such as octamer-binding transcription factor 4 (OCT4). ${ }^{19}$ In humans, almost all oogonia enter meiosis between weeks 9 and 22 of prenatal development or undergo mitotic arrest and are eliminated from the ovaries. ${ }^{19}$ Consequently, neonatal human ovaries generally lack oogonia. Byskov et al reported that there was no evidence for the presence of oogonia in human ovaries after their final clearance during the first 2 years of life. ${ }^{20}$ They analyzed the sections of fetal ovaries 5 to 10 weeks, 18 weeks, or 32 weeks post-conception and from 2- to 32-year-old ovaries using immunohistochemistry. In fetal ovaries, almost all oogonia expressed pluripotency-related markers, such as stage-specific embryonic antigen-4 (SSEA-4), homeobox gene transcription factor (NANOG), OCT4, and tyrosine kinase receptor for stem cell factor (SCF) (C-KIT), whereas only a small proportion of cells were positively stained for melanoma antigen-4 (MAGE-A4). At birth, only a few oogonia expressing these markers were identified while they completely disappeared before the age of 2 years. Later, only diplotene oocytes that positively stained for C-KIT were found in the ovarian sections. Interestingly, from 18 weeks post-conception to 2 years, the medulla contained conglomerates of healthy and degenerating oogonia and small follicles, waste baskets, and oogonia enclosed in growing follicles..$^{20}$ Medulla of older ovaries contained groups of primordial, healthy follicles. It is difficult to explain this in consideration of current knowledge because the follicles are only expected to be present in the ovarian cortex, and one may speculate that in the medulla there are some progenitor 
stem cells enabling their development which perhaps originate from peripheral blood or elsewhere. On the other hand, proliferating oogonia were found in adult ovaries of "lower" primates - prosimians (Strepsirrhines). Ovarian development in the marmoset monkey has not been widely investigated, but the data show that the neonatal marmoset ovary contains numerous oogonia expressing several pluripotency factors such as OCT4A, SALL4, and LIN28A (LIN28). ${ }^{19}$ Altogether, these data demonstrate the primitiveness of the neonatal marmoset ovary in comparison with the human one while also confirming that oogonia, in fact, persisted in adult ovaries through the evolutionary development of primates. Similarly, some scientific evidence exists that shows oogonia can persist into adulthood in some other prosimian species, such as lemurs. ${ }^{21}$

\section{Latest evidence for and against postnatal human oogenesis Germinal stem cells from adult ovaries}

Some researchers very early on struggled against the growing dogma about the finite number of follicles and oocytes at birth. ${ }^{22}$ In spite of the fact that there is no evidence of persistence of oogonia in adult human ovaries, a new idea about germinal (oogonial) stem cells in adult ovaries was developed. ${ }^{23-25}$ This idea was encouraged by some findings on germinal stem cells in both mouse and human postnatal and adult ovaries. Zou et al have successfully established a neonatal mouse germinal stem cell line expressing a normal karyotype and high telomerase activity. ${ }^{26}$ These cells were purified by immunomagnetic isolation and cultured for more than 15 months. Moreover, germinal stem cells were also purified from adult mouse ovaries and cultured for a shorter time - but still more than 6 months. These stem cells were infected with green fluorescent protein (GFP) virus and transplanted into the ovaries of infertile mice. The transplanted cells underwent oogenesis and the mice produced offspring that had the GFP transgene. ${ }^{26}$

The finding in a mouse model was followed by a similar finding in humans. White et al reported the purification of mitotically active germinal stem cells from the ovarian cortex of reproductive-age women. ${ }^{27}$ These cells were purified from the ovarian tissue by fluorescence-activated cell sorting based on DDX4 (VASA) expression. They were rare but mitotically active, and their gene expression profile was quite comparable to primitive germ cells. The authors found that these cells were able to persist in vitro for months and to spontaneously develop into oocyte-like cells with diameters of $35-50 \mu \mathrm{m}$, which were also found to be haploid. When these cells were marked by GFP and xenotransplanted into the human ovarian cortex biopsies or immunodeficient mice, the formation of GFP-positive "oocytes" was observed. It may be criticized that this work was performed in reproductive-age women where potential contamination with the naturally present immature oocytes is not excluded. In addition, the germinal stem cells were isolated from frozen-thawed ovarian tissue that may be damaged, which also increased the possibility of contamination with naturally present immature oocytes. There has also been some criticism of the specificity of the DDX4 (VASA) marker for purification of germinal stem cells from adult ovaries because it can also select immature oocytes from existing early follicles and because experimental evidence of no mitotically active female germinal progenitors in postnatal mouse ovaries was provided, using comparable methodology. ${ }^{28}$ Recently, it was reported that lifelong in vivo cell-lineage tracing of oocytes and follicles in mice did not confirm de novo oogenesis from putative germinal stem cells in adult mice ovaries. ${ }^{29}$ It was shown that the initial pool of oocytes was the only source of germ cells throughout the life span of the studied mice and that no de novo oogenesis occurred under the physiological condition. In addition, there was no evidence for existence of germinal stem cells and neogenesis in adult monkey ovaries. ${ }^{30}$ These findings largely show that more time and further research are needed to clarify the presence and role of germinal stem cells in adult human ovaries.

\section{Ovarian surface epithelium}

\section{as a source of stem cells}

It is possible that the confusion surrounding germinal stem cells could be explained by the fact that the wrong cells were sought in adult human/mammalian ovaries. The experimental evidence showed that in adult human ovaries there might be some other populations of stem cells that may serve as oocyte progenitor cells. Ovarian surface epithelium was early on proposed as a potential source of stem cells, or even primordial follicles, in adult ovaries and was therefore entitled "germinal" epithelium. ${ }^{31}$ Moreover, it has also been found to be an important source of ovarian neoplasms, and it is estimated that approximately $70 \%$ of ovarian cancers are of epithelial origin, specifically originating from the ovarian surface epithelium. ${ }^{32}$ In 2005, Bukovsky et al indeed confirmed in vitro development of oocyte-like cells in cultures of ovarian surface epithelium. ${ }^{33}$ They scraped the ovarian surface epithelium of ovarian cortex biopsies in postmenopausal women, set up cell cultures, and observed the development of oocyte-like cells in vitro. These cells 
expressed some of the oocyte-specific markers, as revealed by immunocytochemistry, but were not analyzed according to their genetic status. The immunocytochemistry data showed that these cells may exhibit oocyte-specific processes, such as GV breakdown, expulsion of the polar body, and surface expression of zona pellucida proteins. The authors found that development of oocyte-like cells was triggered by the presence of phenol red in the culture medium, which could express weak estrogenic activity. ${ }^{34}$ Although the confirmation of oocyte-like cells was weak, this work opened up a new way to study and think about the ovarian surface epithelium. Nevertheless, the putative stem cells from ovarian surface epithelium that developed into oocyte-like cells were not identified, with the cytokeratin-positive mesenchymal progenitor cells being theoretically proposed instead. It has also been proposed that oocyte precursors may develop from ovarian surface epithelium crypts, and granulosa cells from epithelial cords containing stem cells; this principle was suggested to be a base for de novo oogenesis and follicular renewal in postnatal mammalian ovaries. ${ }^{35}$

\section{Small putative stem cells in the ovarian surface epithelium of adult ovaries}

Our group further researched the ovarian surface epithelium cell cultures in terms of potential oogenesis in vitro. ${ }^{36} \mathrm{We}$ scraped the ovarian cortex biopsies in postmenopausal women and of young women with premature ovarian failure (POF), characterized by nonfunctional ovaries and no naturally present follicles and oocytes. Additionally, we developed a laparoscopic procedure to brush the ovarian surface epithelium in women with POF. Similarly to Bukovsky, ${ }^{33}$ we found development of oocyte-like cells in cultures of ovarian surface epithelium and confirmed the expression of some oocytespecific genes, showing that there is really "something" relevant present..$^{36}$ The oocyte-like cells were able to develop into parthenogenetic embryo-like structures. ${ }^{37}$ Moreover, we discovered the first presence of small round cells of unknown origin with diameters of 2 to $4 \mu \mathrm{m}$ among epithelial cells of ovarian surface epithelium brushings (Figure 1), in cultures of ovarian surface epithelium, and also in ovarian sections, as revealed by immunocytochemistry, which we then suggested to be putative stem cells. ${ }^{36,37}$ At that time, the work of Bukovsky ${ }^{33}$ and our work was criticized by Notarianni, ${ }^{38}$ who theoretically provided several aspects (including too simple a culture medium in comparison to human embryonic stem cells [hESCs]) to show that we may be wrong in our interpretation, but did not provide any experimental data to confirm this. Alternatively, Parte et al confirmed our results in human, monkey, sheep, and rabbit testing. ${ }^{39}$ They termed these small putative stem cells from adult ovarian surface epithelium as very small embryonic-like cells (VSELs) according to a very similar population of stem cells expressing pluripotency that was discovered by the Ratajczak research group in human and murine adult bone marrow, peripheral blood, and umbilical cord blood. ${ }^{40-43}$ The VSELs have been proposed to originate from embryonal epiblast and to persist as pluripotent stem cells in adult human tissues and organs. ${ }^{44} 46$ Although the population of small putative stem cells from ovarian surface epithelium and VSELs from bone marrow seem to be quite similar, there has been no direct experimental evidence until now that they represent the same population of cells. It needs to be noted that very similar populations of small ovarian stem cells have also been discovered in monkey, sheep, rabbit, and pig adult ovaries, thus indicating that they might proliferate among different mammalian species. ${ }^{39,47}$

Our further work showed that it is possible to purify small ovarian stem cells from ovarian surface epithelium scrapings by two different methods, based on the expression of SSEA-4: magnetic-activated and fluorescence-activated cell sorting (Figure 2). ${ }^{48}$ The small SSEA-4-positive cells represented a relatively small proportion (up to $10 \%$ ) of all scraped cells. The purification of small putative stem cells from human adult ovaries enabled the genetic analysis and gene expression profiling of these cells using microarrays. The results showed that they expressed several genes related to pluripotency and germinal lineage, especially PGCs. ${ }^{48,49}$ The most prominent genes related to pluripotency were SALL4, CDH1, LIN28B, SOX11, LEFTY1, PP1R9A, MYBL2, and HESRG. They also strongly expressed some genes related to PGCs such as PRDM1 (BLIMP1), PRDM14, and DPPA3 (STELLA) ${ }^{49} \mathrm{All}$ genes related to pluripotency were downregulated in small ovarian stem cells in comparison with hESCs while the PGCrelated gene $P R D M 1$ was upregulated. Interestingly, small ovarian stem cells also expressed some germinal markers, such as DDX4 (VASA), which were upregulated in comparison with hESCs. ${ }^{49}$ All these data showed that small ovarian stem cells expressed a specific pattern of pluripotency and are definitely related to germinal lineage. Moreover, it was found that a very similar population of SSEA-4-positive small cells can be observed and purified from human testicular cell cultures and hESC cultures ${ }^{49}$ Similarly, it has already been reported that small putative stem cells are present in human testicular tissue. ${ }^{50}$ On the other hand, these small putative stem cells were then discovered in hESC cultures for the first time. We suggest them to be the "real" hESCs that may persist in adult human tissues and organs, including gonads, 


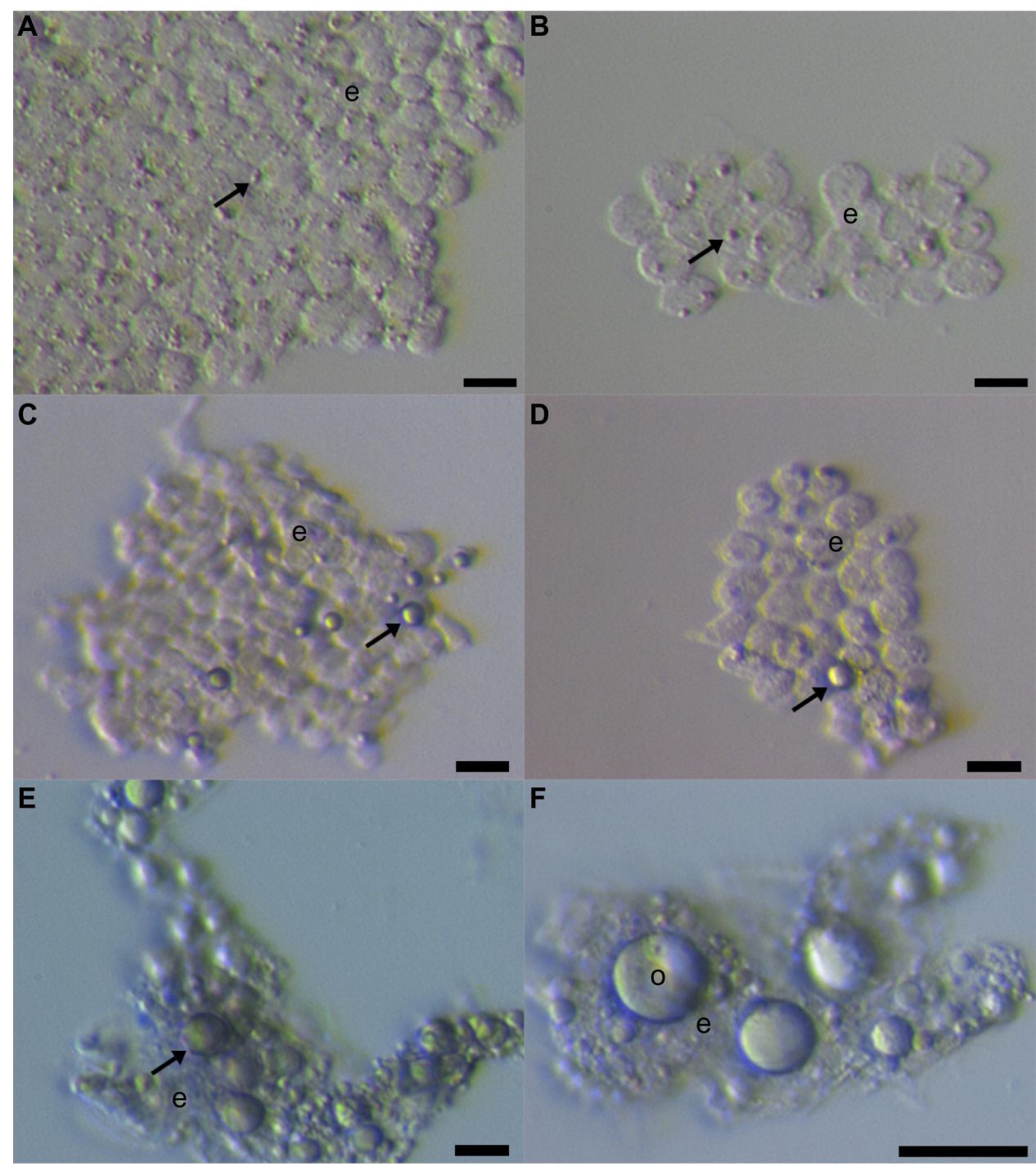

Figure I Small putative stem cells among epithelial cells after laparoscopic brushing of the ovarian surface epithelium in the same patient with premature ovarian failure and no naturally present follicles and oocytes.

Notes: (A, B) Small stem cells (arrows) among epithelial cells (e) just after laparoscopic brushing of the ovarian surface epithelium. (C, D) Small stem cells (arrows) were starting to grow and proliferate after short-term culturing of brushings in a culture medium with added follicular fluid from the in vitro fertilization program. (E, F) Small stem cells (arrow) grew into primitive oocyte-like cells (o) after long-term culturing of brushings in a culture medium with added follicular fluid from the in vitro fertilization program. Scale bars: (A-E) $10 \mu \mathrm{m}$; (F) $50 \mu \mathrm{m}$.

Abbreviations: e, epithelial cells; o, oocyte-like cells.

in a dormant state from the embryonic period of life; however, it is too early to make a real conclusion.

\section{Oocyte-like cells from small ovarian stem cells}

Our data showed that small putative ovarian stem cells from human adult ovaries - ovarian surface epithelium - can grow and develop into oocyte-like cells in vitro. ${ }^{36,37,48,51}$ They can also grow into oocyte-like cells in cell cultures of scraped ovarian surface epithelium spontaneously or, especially, after triggering by follicular fluid retrieved in the in vitro fertilization program upon oocyte retrieval after ovarian hormonal stimulation. This could be expected, as follicular fluid is known to be rich in reproductive hormones (estrogens, progesterone, follicle-stimulating hormone [FSH], androgens) and several other substances important for oocyte growth and maturation, such as proteins, amino acids, lipids (including free cholesterol and meiosis-activating sterol), growth factors, and more. ${ }^{52-56}$ Oocyte-like cells have even been retrieved in women with POF, diagnosed by histology, serum hormonal level, and ultrasound; these women were characterized by having no naturally present follicles and oocytes. ${ }^{36,51,57}$ The oocyte-like cells grew up to $60-80 \mu \mathrm{m}$ and did not express zona pellucida. The oocyte-like cells were taken from cell cultures and, as single cells, analyzed by realtime quantitative polymerase chain reaction in comparison 


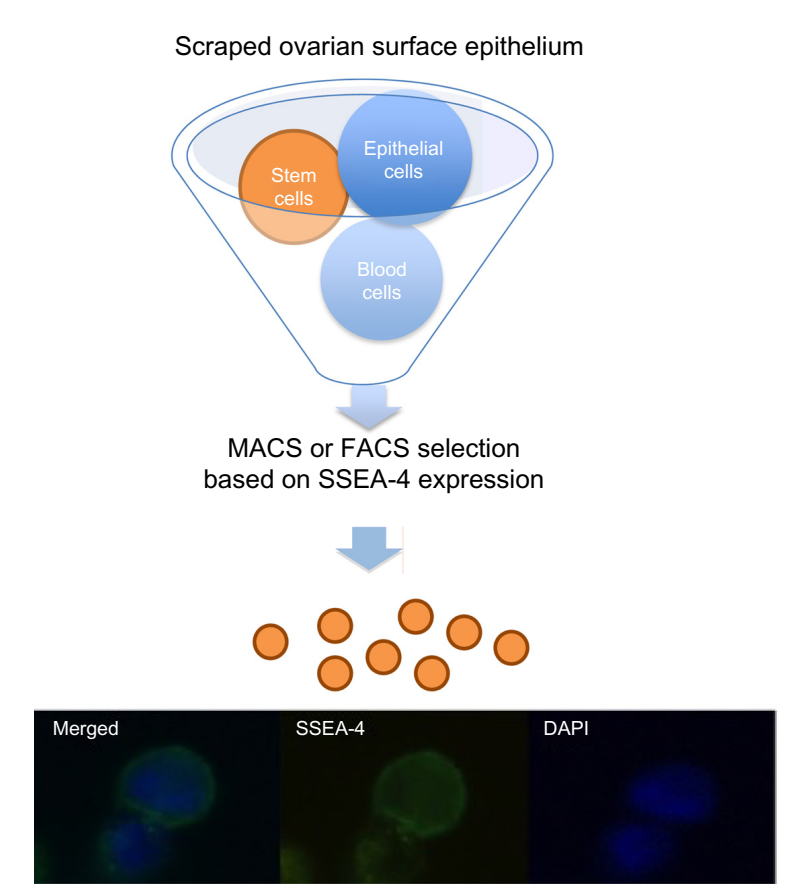

Small ovarian stem cells with diameters of $2-4 \mu \mathrm{m}$ expressing SSEA-4

Figure 2 Selection of small putative stem cells from cells scraped from the ovarian surface epithelium based on the expression of SSEA-4 surface antigen.

Notes: Adapted from Virant-Klun I, Skutella T, Hren M, et al. Isolation of small SSEA-4-positive putative stem cells from the ovarian surface epithelium of adult human ovaries by two different methods. Biomed Res Int. 2013;2013:6904I5. ${ }^{78}$ Adapted from Virant-Klun I, Stimpfel M, Cvjeticanin B, Vrtacnik-Bokal E, Skutella T. Small SSEA-4-positive cells from human ovarian cell cultures: related to embryonic stem cells and germinal lineage? J Ovarian Res. 2013;6:24.49

Abbreviations: DAPI, 4',6-diamidino-2-phenylindole; FACS, fluorescence-activated cell sorting; MACS, magnetic-activated cell sorting.

with non-fertilized oocytes from the in vitro fertilization program, hESCs, and somatic fibroblasts. ${ }^{51}$ It was found that oocyte-like cells were heterogeneous at the genetic level, but some of them expressed several genes related to pluripotency and oocytes (including meiosis-related genes) and matched with oocytes and hESCs closer than with adult fibroblasts. ${ }^{51}$ In spite of that, the oocyte-like cells were far from being competent oocytes (even immature oocytes). They more represented stem cells "pushed" into the germinal direction than "real" oocytes.

Based on experimental experience, we proposed small ovarian stem cells to be germ cell progenitors related to PGCs that might be pre-stage of germinal stem cells, oogonia, and oocytes.

\section{Small ovarian stem cells, blood cells, cells of the immune system, or microvesicles?}

The small ovarian stem cells could be mixed with something else, like blood cells (erythrocytes) or cells from the immunological system (lymphocytes). Moreover, there was also some suggestion that small ovarian stem cells might be microvesicles, yet several characteristics about them dispel such suggestions (Table 1). ${ }^{57-60}$ After May-GrünwaldGiemsa staining, commonly used to stain blood smears, the small ovarian stem cells scraped from the ovarian surface epithelium either did not stain or only weakly stained, while all blood cells, including lymphocytes, strongly stained, as evidenced by our previous work ${ }^{57}$ and Figure 3 . The small stem cells scraped from the ovarian surface epithelium had completely round nuclei which filled almost the entire cell volumes, as revealed by Hoechst 33258 (Sigma Aldrich Co, St Louis, MO, USA) staining (Figure 2). Erythrocytes were indeed the predominating blood cells in a population of cells scraped from the ovarian surface epithelium, but small ovarian stem cells were differentiated by being significantly smaller (Table 1). Blood cells represented about $1 \%$ of all scraped cells, a minority among other types of scraped cells, such as epithelial cells, as revealed by MayGrünwald-Giemsa staining. The small, round stem cells could be comparable to lymphocytes due to their round shape and high nuclear/cytoplasm ratio, but they were significantly smaller. Moreover, the lymphocytes were positively stained after May-Grünwald-Giemsa staining, while small round cells were not. ${ }^{57}$ The small ovarian stem cells always appeared to be completely round, did not change their shape, and were significantly larger than microvesicles (Table 1). The abovementioned populations of cells also expressed different biomarkers, therefore they cannot be mixed regarding their molecular status. Small ovarian stem cells composed the only population of cells that expressed at least some markers of pluripotency and germinal lineage and were shown being pushed into the germinal direction, while all other types of cells did not (Table 1). ${ }^{36,37,39,48,51,57}$

\section{Oocytes from other pluripotent stem cells: ESCs, induced pluripotent stem cells, and others}

The ovarian stem cells are the most interesting population of cells for potential autologous de novo oogenesis and regeneration of nonfunctional ovaries in infertile women, although the data show that oocyte-like cells which express some oocyte-specific markers can also be developed from other populations of pluripotent stem cells, such as ESCs and induced pluripotent stem cells. ${ }^{61-67}$ Moreover, it has also been reported that oocyte-like cells can be developed from human amniotic fluid stem cells, and even from pancreatic stem cells and embryonal dermal skin cells in animal models. ${ }^{68-71}$ In all these cases, the oocyte-like cells were developed from stem cells that expressed at least a degree 
Table I Comparison of small ovarian stem cells, blood cells (erythrocytes), cells of the immune system (lymphocytes), and microvesicles ${ }^{49,57-60}$

\begin{tabular}{|c|c|c|c|c|}
\hline \multirow[t]{2}{*}{ Feature } & \multicolumn{4}{|l|}{ Type of cells } \\
\hline & Small ovarian stem cells & Erythrocytes & Lymphocytes & Microvesicles \\
\hline Presence of nucleus & + & - & + & - \\
\hline DAPI staining & + & - & + & + \\
\hline Diameters & $2-4 \mu \mathrm{m}$ & $\begin{array}{l}\text { Young: } 7.77 \mu \mathrm{m} \text {, } \\
\text { middle-aged: } 7.34 \mu \mathrm{m} \text {, } \\
\text { old: } 7.00 \mu \mathrm{m}\end{array}$ & $6-9 \mu \mathrm{m}$ & $\begin{array}{l}50 / 100-1,000 \mathrm{~nm} \\
(0.1-1.0 \mu \mathrm{m})\end{array}$ \\
\hline $\begin{array}{l}\text { May-Grünwald- } \\
\text { Giemsa staining }\end{array}$ & - & + & + & - \\
\hline Shape & Round & Oval biconcave disk & $\begin{array}{l}\text { Different (spherical, } \\
\text { polarized or non-polarized } \\
\text { with surface projections) }\end{array}$ & $\begin{array}{l}\text { Different (small fragments of } \\
\text { plasma membrane expressing } \\
\text { different shapes) }\end{array}$ \\
\hline $\begin{array}{l}\text { Nucleus/cell } \\
\text { proportion }\end{array}$ & $\begin{array}{l}\text { Circular nuclei occupying } \\
\text { most of the cell volume }\end{array}$ & & $\begin{array}{l}\text { Circular nuclei occupying } \\
\text { most of the cell volume }\end{array}$ & \\
\hline Markers & $\begin{array}{l}\text { SSEA4, PRDMI, } \\
\text { DPPA3, SALL4, alkaline } \\
\text { phosphatase, etc }\end{array}$ & $\begin{array}{l}\text { Acetylcholinesterase, AMP } \\
\text { deaminase, band } 3 \text { (cdb3), } \\
\text { BGPI, CD 36, CD47, CD7I, } \\
\text { CD235a, hemoglobin, } \\
\text { creatine, glycophorin A and B, } \\
\text { chromium 5I, TERII9, etc }\end{array}$ & $\begin{array}{l}\text { CDI6, CD56, CD3, CD4, } \\
\text { TCR } \alpha \beta, C D 8, T C R \gamma \delta \text {, } \\
\text { MHC class II, CDI9, } \\
\text { CD2I, etc }\end{array}$ & $\begin{array}{l}\text { Heat-shock proteins (HSP70, } \\
\text { HSP90), CD9, CD37, CD63, } \\
\text { CD8I, CD82, CDI06, Tspan8, } \\
\text { flotillin-I, MMP2, MMP9, } \\
\text { EMMPRIN, ARF6, MUCI, CBI, } \\
\text { caveolin-I, Rab-5a, Rab-5B, Alix, } \\
\text { etc }\end{array}$ \\
\hline $\begin{array}{l}\text { Pluripotency- } \\
\text { related markers }\end{array}$ & $\begin{array}{l}\text { + (SSEA-4, SALL4, CDHI, } \\
\text { LIN28B, SOXII, LEFTYI, } \\
\text { PPIR9A, MYBL2, HESRG, etc) }\end{array}$ & - & - & - \\
\hline Germinal markers & $\begin{array}{l}+(\text { DPPA3, PRDMI, } \\
\text { PRDMI } 4, \text { VASA, etc })\end{array}$ & - & - & - \\
\hline Specificity & $\begin{array}{l}\text { Development of oocyte-like } \\
\text { cells in vitro }\end{array}$ & & & $\begin{array}{l}\text { Transport of mRNA, miRNA, } \\
\text { and proteins between cells }\end{array}$ \\
\hline
\end{tabular}

Abbreviations: DAPI, 4',6-diamidino-2-phenylindole; mRNA, messenger ribonucleic acid; miRNA, micro-ribonucleic acid.

of pluripotency, and the resulting oocyte-like cells expressed some germinal markers but were still far from being real and competent oocytes. ${ }^{49,51,62,71}$ Despite this limited outcome, all these studies are quite promising and indicate that development of gametes - oocytes - from stem cells might be shown as valid one day.

\section{In vitro oogenesis or transplantation of pluripotent stem cells into insufficient ovaries?}

In vitro maturation of human oocytes is one of the most difficult tasks in the in vitro fertilization program. On one hand, the procedure of human oocyte in vitro maturation is still a low-success procedure due to suboptimal culture conditions and, on the other hand, it may also possess some epigenetic risk, although, for the most part, not experimentally confirmed in humans. ${ }^{72-75}$ One of the main reasons for this lies in several known and unknown substances and factors, which are involved in the oocyte maturation process in the follicular/ovarian niche and are not present when the immature oocyte is exposed to in vitro conditions. Epigenetic regulation is being established only near the end of oocyte maturation in natural conditions and may be incomplete or even broken when immature oocytes are exposed to in vitro conditions and suboptimal in vitro maturation procedures. In the in vitro fertilization program, immature GV oocytes can be retrieved from the ovaries of women with polycystic ovary syndrome to be matured in vitro, both to avoid the hormonal stimulation of their ovaries and to prevent potential ovarian hyperstimulation syndrome. ${ }^{76,77}$ In spite of such effort, the data show that the oocytes matured in vitro result in low clinical success. ${ }^{78}$ The in vitro matured oocytes result in worse embryo development and poor clinical outcomes in terms of pregnancy and birth. This may be a consequence of deleterious effects of in vitro maturation on the organization of the meiotic spindle and of the chromosome alignment of human oocytes particular to oocyte-like cells developed from stem cells, which are still far from the GV stage of oocyte maturity. ${ }^{79}$ This means that the procedure of oocyte in vitro maturation, including oocyte-like cells developed from stem cells, needs to be further researched.

It has been proposed that transplantation of stem cells or stem cell-derived "oocytes" into the ovary or other organs would be of great advantage because it would provide a 


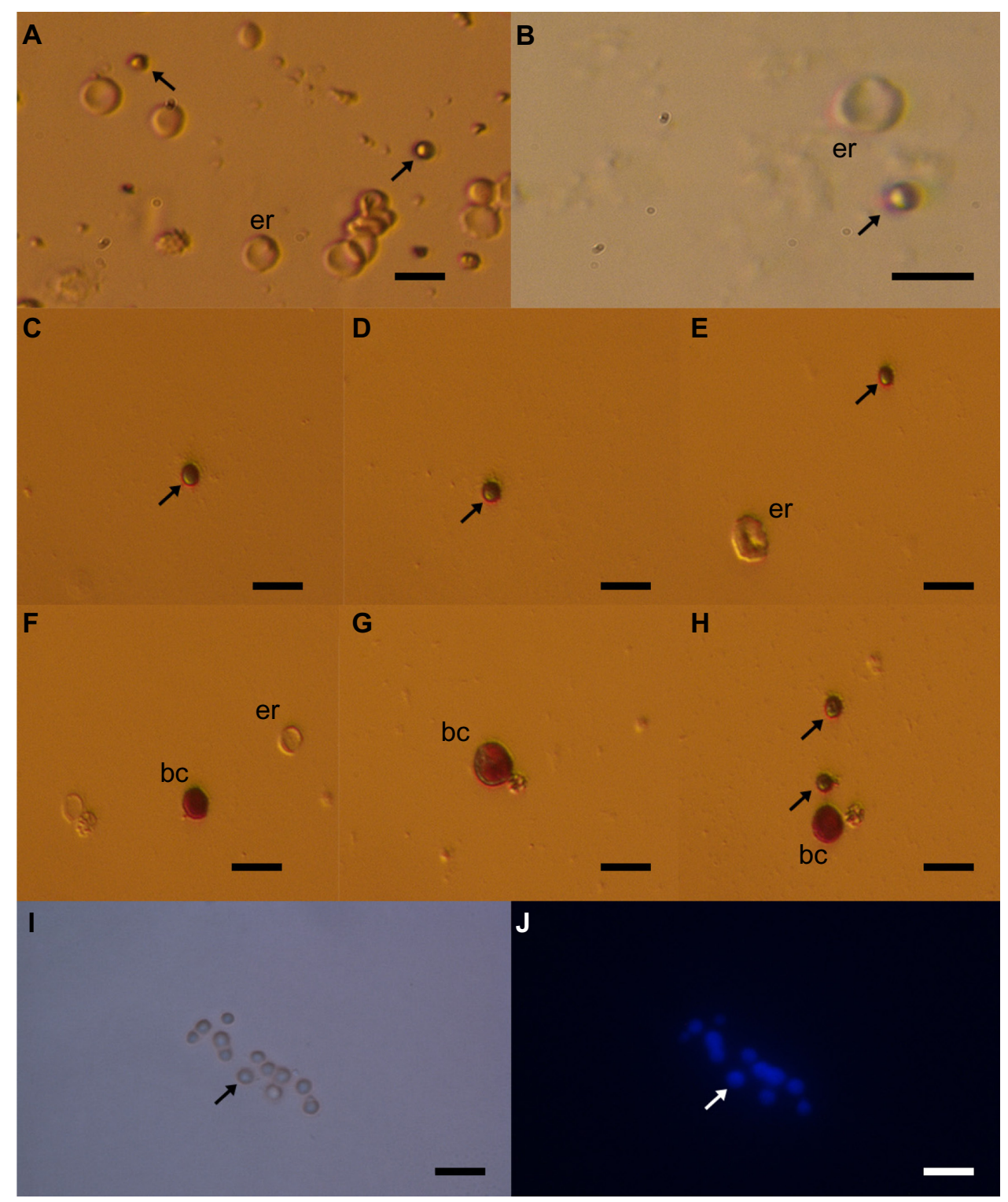

Figure 3 Small putative stem cells (arrows) from ovarian surface epithelium in a patient with premature ovarian failure and no naturally present follicles and oocytes. Notes: (A and B) Small stem cells among other cells (mostly epithelial cells and erythrocytes [er]) after scraping of the ovarian surface epithelium (ovarian cortex biopsy). (C-E and $\mathbf{H}$ ) Small stem cells not stained or weakly stained by May-Grünwald-Giemsa staining. (F-H) Blood cells (bc) strongly stained by May-Grünwald-Giemsa staining (red). (I,J) In small stem cells nucleus filled almost the entire cell volume of stem cells after Hoechst 33258 (Sigma Aldrich Co, St Louis, MO, USA) staining (blue). Scale bars: I0 $\mu$ m.

natural niche for maturation of oocytes and bypass several obstacles related to oocyte in vitro maturation. ${ }^{80}$ In a mouse model it was confirmed that ESC-derived oocyte maturation ultimately fails in vitro, and to overcome this obstacle the transplantation of ESC-derived "oocytes" into an ovarian niche has been proposed in order to direct their natural and functional maturation. Indeed, the ESC-derived "oocyte" maturation was shown in newly formed ovarian follicles after transplantation into the mouse ovarian niche. ${ }^{80}$ The ESC-derived "oocytes" were enclosed in ovarian follicles, and some of them reached the primordial or primary stage of development. The primary follicles consisted of an
ESC-derived "oocyte", expressing some germinal markers, with a single layer of endogenous cuboidal granulosa cells, surrounded by a basement membrane ${ }^{80}$ Recently, it was reported that artificial mouse/rat PGCs were induced in vitro from pluripotent stem cells, enzymatically dispersed, and transplanted together with PGC-free gonadal cells under the kidney capsule of xenogenic immunodeficient animals. ${ }^{81}$ The transplanted PGCs formed ovary-like tissue that was histologically similar to the normal ovary and also expressed the oocyte-related markers Vasa and Stella. In addition, the mouse GV-stage oocyte-like cells were collected from the ovary-like tissue in rats. These oocytes were matured in vitro 
to metaphase II stage and gave rise to offspring using intracytoplasmic sperm injection. ${ }^{81}$ All these data show that transplantation of stem cells or "oocytes" derived from this process into the natural ovarian niche may represent a more optimal and reliable approach to deriving competent "oocytes" from stem cells in infertile women than in vitro oogenesis. ${ }^{82}$ Moreover, the assisted conception is based on well-developed and experienced ovarian hormonal stimulation protocols under perfectly controlled conditions and results in the functional in vivo maturation of follicles and oocytes in humans. These protocols might be quite helpful in supporting the in vivo maturation of stem cell-derived "oocytes" in the future.

\section{Therapeutic/clinical potential of postnatal oogenesis in humans}

Postnatal oogenesis could be of great importance for clinical practice in the field of reproductive medicine. Some young patients suffer from nonfunctional ovaries (ovarian insufficiency or premature ovarian failure) or from poor ovarian response to hormonal stimulation, performed to retrieve oocytes for in vitro fertilization. POF is a common condition which affects approximately one out of 100 women and is characterized by amenorrhea, hypoestrogenism, and elevated gonadotropin levels in women under the age of 40 years. ${ }^{83}$ Nonfunctional ovaries may be a natural condition related to abnormalities of chromosome $\mathrm{X}$, such as fragile $\mathrm{X}$ permutation ( $\sim 5 \%)$; familial genetic causes including abnormalities of genes such as FOXL2, FSHR, and INHA ( 20\%); autoimmunity with anti-ovary antibodies $(\sim 10 \%)$ or other idiopathic factors $(\sim 65 \%)$; or an artificial consequence of aggressive therapy (chemotherapy or radiotherapy) of different cancers including childhood cancers, Hodgkin's lymphoma, and breast cancer. ${ }^{84}$ Autologous stem cells in these patients could be used to develop into "oocytes" to be fertilized in vitro, or they may be transplanted into the insufficient ovaries to regenerate them. This approach would be safer than the cryopreservation and autotransplantation of thawed ovarian tissue in cancer patients that is an established practice worldwide but without the risk of retransplantation of malignant cells into the body. ${ }^{85}$

\section{Regeneration of ovaries by mesenchymal stem cell transplantation}

Development of oocytes from stem cells does not represent the only challenge in reproductive medicine. The limits between different types of stem cells are not clear, and a greater number of reports confirmed that mesenchymal stem cells (MSCs) may also possess a degree of pluripotency, including those from human testicles. ${ }^{86}$ Consequently, they may be used to regenerate the nonfunctional ovaries. Indeed, several studies in animal models showed that transplantation of animal or human MSCs from different sources may regenerate nonfunctional ovaries, pre-sterilized by cyclophosphamide, an alkylating antineoplastic agent, which is also used in human medicine (chemotherapy), and/or busulfan. ${ }^{87-94}$ The transplanted cells appear not to develop into oocytes but mostly support the surrounding granulosa cells, which are known to be of mesodermal (mesenchymal) origin, and the general ovarian physiology, thus indirectly supporting the postnatal oogenesis/folliculogenesis.

It was found that intravenous injection of male bone marrow-derived MSCs into rabbits with chemotherapyinduced ovarian damage improved ovarian function. ${ }^{87}$ The MSCs accomplished this function by direct differentiation into specific cellular phenotypes and by decreasing FSH while increasing estrogen and vascular endothelial growth factor (VEGF) levels to positively influence the regeneration of the ovaries. Cytological and histological examinations confirmed the increased numbers of follicles with normal structure in the MSC recipient group of animals. ${ }^{87}$ Similarly, in another study, the transplantation of bone marrow-derived MSCs decreased germ cell apoptosis and DNA damage while increasing the number of primordial follicles after chemotherapy regimens in rats. ${ }^{88}$

It was also discovered that human amniotic fluid contains a population of CD44/CD105-positive human amniotic fluid stem cells (hAFCs) that rapidly proliferate and highly express the proliferative markers, a number of biomarkers of MSCs, and even some biomarkers and properties of pluripotent stem cells and germinal lineage under continuous subculture in vitro. ${ }^{89,90}$ Moreover, they had the ability to restore ovarian morphology after transplantation into the ovaries of mice presterilized by intraperitoneal injection of cyclophosphamide and busulfan. In these transplanted mice, the ovaries were restored and displayed increased levels of anti-Müllerian hormone (AMH), a functional marker of folliculogenesis, and many follicle-enclosed oocytes at all stages of development, while in control sterilized mice without transplantation they did not. ${ }^{90,91}$ Furthermore, it was confirmed that transplantation of MSCs from other sources, such as human umbilical cord blood matrix (Wharton's jelly) or mouse adipose tissuederived stem cells (ADSC), can effectively restore ovarian functionality and reduce apoptosis of granulosa cells in animals with cyclophosphamide/busulfan-induced premature 
ovarian failure. ${ }^{92-94}$ The main worry of these studies is the potentially incomplete sterilization of ovaries in animals; therefore, some additional and more relevant models of premature ovarian failure would need to be applied to these types of studies.

Recently, such studies have also been applied in human medicine, but the results have not been published yet. Recently, putative MSCs were also found in human adult ovaries and represent an extremely interesting tool for regenerating the sterile ovaries in humans. ${ }^{95}$ Nevertheless, the MSCs would need to be applied with the same caution as pluripotent stem cells to prevent potential teratoma formation or other complications in humans.

\section{Conclusion}

Studies on this topic are intensely ongoing, and time will tell which approach could be optimal for use in clinical practice to treat ovarian infertility in young women at reproductive age who wish to have a child. Nevertheless, more and deeper research into this area is needed for future and better understanding of stem cells and competent oocytes in humans. The data show that there are different populations of stem cells in adult human ovaries; therefore, the postnatal oogenesis/ folliculogenesis cannot be excluded. Perhaps existing stem cells enable the persistence of a sufficient number of follicles in adult ovaries to produce functional oocytes during the reproductive period of life, although the overall number of follicles decreases over a long lifespan. Both oogenesis in vitro and transplantation of stem cell-derived "oocytes" into the ovarian niche to direct their natural maturation represent major challenges in reproductive biomedicine to treat female infertility in the future. Above all, this needs to be researched and interpreted with great caution to avoid the risk of tumor formation (stem cell expression of pluripotency) and false hope in patients.

\section{Disclosure}

The author reports no conflict of interest in this work.

\section{References}

1. Waldeyer W. Eierstock und Ei. Ein Beitrag zur Anatomie und Entwicklungsgeschichte der Sexualorgane [Ovary and Egg. A Contribution to the Anatomy and Evolution of the Sexual Organs]. Leipzig: Engelmann; 1870. German.

2. Kingery HM. Oogenesis in the white mouse. J Morphol. 1917;30: 261-315.

3. Allen E. Ovogenesis during sexual maturity. Am J Anat. 1923;31: 439-481.

4. Evans HM, Swezy O. Ovogenesis and the normal follicular cycle in adult Mammalia. Cal West Med. 1932;36(1):60.
5. Bukovsky A, Copas P, Virant-Klun I. Potential new strategies for the treatment of ovarian infertility and degenerative diseases with autologous ovarian stem cells. Expert Opin Biol Ther. 2006;6(4): 341-365.

6. Rodrigues P, Limback D, McGinnis LK, Plancha CE, Albertini DF. Oogenesis: prospects and challenges for the future. J Cell Physiol. 2008;216(2):355-365.

7. Johnson MH, Everitt BJ. Essential Reproduction. 5th ed. Oxford: Blackwell Science; 2000.

8. Block E. Quantitative morphological investigations of the follicular system in women; variations at different ages. Acta Anat (Basel). 1952;14(1-2):108-123.

9. Block E. A quantitative morphological investigation of the follicular system in newborn female infants. Acta Anat (Basel). 1953;17(3): 201-206.

10. Baker TG. A quantitative and cytological study of germ cells in human ovaries. Proc R Soc Lond B Biol Sci. 1963;158:417-433.

11. Gougeon A, Chainy GB. Morphometric studies of small follicles in ovaries of women of different ages. J Reprod Fertil. 1987;81(2): 433-442.

12. Richardson SJ, Senikas V, Nelson JF. Follicular depletion during the menopausal transition: evidence for accelerated loss and ultimate exhaustion. J Clin Endocrinol Metab. 1987;65(6):1231-1237.

13. Hansen KR, Knowlton NS, Thyer AC, Charleston JS, Soules MR, Klein NA. A new model of reproductive aging: the decline in ovarian non-growing follicle number from birth to menopause. Hum Reprod. 2008;23(3):699-708.

14. Bendsen E, Byskov AG, Andersen CY, Westergaard LG. Number of germ cells and somatic cells in human fetal ovaries during the first weeks after sex differentiation. Hum Reprod. 2006;21(1):30-35.

15. Forabosco A, Sforza C. Establishment of ovarian reserve: a quantitative morphometric study of the developing human ovary. Fertil Steril. 2007;88(3):675-683.

16. Faddy MJ, Gosden RG, Gougeon A, Richardson SJ, Nelson JF. Accelerated disappearance of ovarian follicles in mid-life: implications for forecasting menopause. Hum Reprod. 1992;7(10):1342-1346.

17. Faddy MJ, Gosden RG. A model conforming the decline in follicle numbers to the age of menopause in women. Hum Reprod. 1996;11(7): 1484-1486.

18. Wallace WH, Kelsey TW. Human ovarian reserve from conception to the menopause. PLoS One. 2010;5(1):e8772.

19. Fereydouni B, Drummer C, Aeckerle N, Schlatt S, Behr R. The neonatal marmoset monkey ovary is very primitive exhibiting many oogonia. Reproduction. 2014;148(2):237-247.

20. Byskov AG, Høyer PE, Yding Andersen C, Kristensen SG, Jespersen A, Møllgård K. No evidence for the presence of oogonia in the human ovary after their final clearance during the first two years of life. Hum Reprod. 2011;26(8):2129-2139.

21. Gosden RG. Ovulation 1: oocyte development throughout life. In: Grudzinskas JG, Yovich JL, editors. Gametes. The Oocyte. Cambridge: Cambridge University Press; 1995:119-127.

22. Zuckerman S. The number of oocytes in the mature ovary. Rec Prog Horm Res. 1951;6:63-108.

23. Oatley J, Hunt PA. Of mice and (wo)men: purified oogonial stem cells from mouse and human ovaries. Biol Reprod. 2012;86(6):196.

24. Vogel G. Reproductive biology. Potential egg stem cells reignite debate. Science. 2012;335(6072):1029-1030.

25. Ghazal S. Oogonial stem cells: do they exist and may they have an impact on future fertility treatment? Curr Opin Obstet Gynecol. 2013; 25(3):223-228.

26. Zou K, Yuan Z, Yang Z, et al. Production of offspring from a germline stem cell line derived from neonatal ovaries. Nat Cell Biol. 2009;11(5): 631-636.

27. White YA, Woods DC, Takai Y, Ishihara O, Seki H, Tilly JL. Oocyte formation by mitotically active germ cells purified from ovaries of reproductive-age women. Nat Med. 2012;18(3):413-421. 
28. Zhang H, Zheng W, Shen Y, Adhikari D, Ueno H, Liu K. Experimental evidence showing that no mitotically active female germline progenitors exist in postnatal mouse ovaries. Proc Natl Acad Sci U S A. 2012; 109(31):12580-12585.

29. Zhang H, Liu L, Li X, et al. Life-long in vivo cell-lineage tracing shows that no oogenesis originates from putative germline stem cells in adult mice. Proc Natl Acad Sci U S A. 2014;111(50): 17983-17988.

30. Yuan J, Zhang D, Wang L, et al. No evidence for neo-oogenesis may link to ovarian senescence in adult monkey. Stem Cells. 2013;31(11): 2538-2550.

31. Ludwig KS. [On the question of primordial follicles from the germinal epithelium during puberty in the human ovary]. Experientia. 1965; 21(8):469-471. German.

32. Abell MR. The nature and classification of ovarian neoplasms. Can Med Assoc J. 1966;94(21):1102-1124.

33. Bukovsky A, Svetlikova M, Caudle MR. Oogenesis in cultures derived from adult human ovaries. Reprod Biol Endocrinol. 2005;3:17.

34. Ortmann O, Sturm R, Knuppen R, Emons G. Weak estrogenic activity of phenol red in the pituitary gonadotroph: re-evaluation of estrogen and antiestrogen effects. J Steroid Biochem. 1990;35(1):17-22.

35. Bukovsky A, Gupta SK, Virant-Klun I, Upadhyaya NB, Copas P, Van Meter SE, et al. Study origin of germ cells and formation of new primary follicles in adult human and rat ovaries. Methods Mol Biol. 2008;450:233-265.

36. Virant-Klun I, Zech N, Rozman P, et al. Putative stem cells with an embryonic character isolated from the ovarian surface epithelium of women with no naturally present follicles and oocytes. Differentiation. 2008;76(8):843-856.

37. Virant-Klun I, Rozman P, Cvjeticanin B, et al. Parthenogenetic embryolike structures in the human ovarian surface epithelium cell culture in postmenopausal women with no naturally present follicles and oocytes Stem Cells Dev. 2009;18(1):137-149. Erratum in: Stem Cells Dev. 2009;18(7):1109.

38. Notarianni E. Reinterpretation of evidence advanced for neo-oogenesis in mammals, in terms of a finite oocyte reserve. J Ovarian Res. 2011; 4(1):1.

39. Parte S, Bhartiya D, Telang J, et al. Detection, characterization, and spontaneous differentiation in vitro of very small embryonic-like putative stem cells in adult mammalian ovary. Stem Cells Dev. 2011;20(8): 1451-1464.

40. Kucia M, Reca R, Campbell FR, et al. A population of very small embryonic-like (VSEL) CXCR4(+)SSEA-1(+)Oct-4+ stem cells identified in adult bone marrow. Leukemia. 2006;20(5):857-869.

41. Kucia M, Zuba-Surma E, Wysoczynski M, et al. Physiological and pathological consequences of identification of very small embryonic like (VSEL) stem cells in adult bone marrow. J Physiol Pharmacol. 2006;57 Suppl 5:5-18.

42. Kucia MJ, Wysoczynski M, Wu W, Zuba-Surma EK, Ratajczak J, Ratajczak MZ. Evidence that very small embryonic-like stem cells are mobilized into peripheral blood. Stem Cells. 2008;26(8):2083-2092.

43. Kucia M, Halasa M, Wysoczynski M, et al. Morphological and molecular characterization of novel population of CXCR4+ SSEA-4+ Oct-4+ very small embryonic-like cells purified from human cord blood: preliminary report. Leukemia. 2007;21(2):297-303.

44. Ratajczak MZ, Machalinski B, Wojakowski W, Ratajczak J, Kucia M. A hypothesis for an embryonic origin of pluripotent Oct-4(+) stem cells in adult bone marrow and other tissues. Leukemia. 2007;21(5): 860-867.

45. Shin DM, Liu R, Wu W, et al. Global gene expression analysis of very small embryonic-like stem cells reveals that the Ezh2-dependent bivalent domain mechanism contributes to their pluripotent state. Stem Cells Dev. 2012;21(10):1639-1652.

46. Shin DM, Zuba-Surma EK, Wu W, et al. Novel epigenetic mechanisms that control pluripotency and quiescence of adult bone marrow-derived Oct4(+) very small embryonic-like stem cells. Leukemia. 2009;23(11): 2042-2051.
47. Bui HT, Van Thuan N, Kwon DN, et al. Identification and characterization of putative stem cells in the adult pig ovary. Development. 2014; 141(11):2235-2244.

48. Virant-Klun I, Skutella T, Hren M, et al. Isolation of small SSEA-4-positive putative stem cells from the ovarian surface epithelium of adult human ovaries by two different methods. Biomed Res Int. 2013;2013: 690415.

49. Virant-Klun I, Stimpfel M, Cvjeticanin B, Vrtacnik-Bokal E, Skutella T. Small SSEA-4-positive cells from human ovarian cell cultures: related to embryonic stem cells and germinal lineage? J Ovarian Res. 2013;6:24.

50. Bhartiya D, Kasiviswananthan S, Shaikh A. Cellular origin of testisderived pluripotent stem cells: a case for very small embryonic-like stem cells. Stem Cells Dev. 2012;21(5):670-674.

51. Virant-Klun I, Skutella T, Kubista M, Vogler A, Sinkovec J, MedenVrtovec H. Expression of pluripotency and oocyte-related genes in single putative stem cells from human adult ovarian surface epithelium cultured in vitro in the presence of follicular fluid. Biomed Res Int. 2013;2013:861460.

52. Duijkers IJ, Willemsen WN, Hollanders HM, Hamilton CJ, Thomas CM, Vemer HM. Follicular fluid hormone concentrations after ovarian stimulation using gonadotropin preparations with different $\mathrm{FSH} / \mathrm{LH}$ ratios. II. Comparison of hMG and recombinant FSH. Int J Fertil Womens Med. 1997;42(6):431-435.

53. Velazquez A, Reyes A, Chargoy J, Rosado A. Amino acid and protein concentrations of human follicular fluid. Fertil Steril. 1977;28(1): 96-100.

54. Bokal EV, Tacer KF, Vrbnjak M, et al. Follicular sterol composition in gonadotrophin stimulated women with polycystic ovarian syndrome. Mol Cell Endocrinol. 2006;249(1-2):92-98.

55. Smitz J, Picton HM, Platteau P, et al. Principal findings from a multicenter trial investigating the safety of follicular-fluid meiosis-activating sterol for in vitro maturation of human cumulus-enclosed oocytes. Fertil Steril. 2007;87(4):949-964.

56. Ulug U, Turan E, Tosun SB, Erden HF, Bahceci M. Comparison of preovulatory follicular concentrations of epidermal growth factor, insulinlike growth factor-I, and inhibins A and B in women undergoing assisted conception treatment with gonadotropin-releasing hormone $(\mathrm{GnRH})$ agonists and GnRH antagonists. Fertil Steril. 2007;87(4):995-998.

57. Virant-Klun I, Skutella T, Stimpfel M, Sinkovec J. Ovarian surface epithelium in patients with severe ovarian infertility: a potential source of cells expressing markers of pluripotent/multipotent stem cells. J Biomed Biotechnol. 2011;2011:381928.

58. Vömel T, Platt D, Strobelt W. Diameters of erythrocytes of different ages measured by scanning electron-microscopy. Mech Ageing Dev. 1980;13(4):357-365.

59. Kuse R, Schuster S, Schübbe H, Dix S, Hausmann K. Blood lymphocyte volumes and diameters in patients with chronic lymphocytic leukemia and normal controls. Blut. 1985;50(4):243-248.

60. Lee Y, El Andaloussi S, Wood MJ. Exosomes and microvesicles: extracellular vesicles for genetic information transfer and gene therapy. Hum Mol Genet. 2012;21(R1):R125-R134.

61. Hübner K, Fuhrmann G, Christenson LK, et al. Derivation of oocytes from mouse embryonic stem cells. Science. 2003;300(5623): 1251-1256.

62. Novak I, Lightfoot DA, Wang H, Eriksson A, Mahdy E, Höög C. Mouse embryonic stem cells form follicle-like ovarian structures but do not progress through meiosis. Stem Cells. 2006;24(8):1931-1936.

63. West FD, Machacek DW, Boyd NL, Pandiyan K, Robbins KR, Stice SL. Enrichment and differentiation of human germ-like cells mediated by feeder cells and basic fibroblast growth factor signaling. Stem Cells 2008;26(11):2768-2776.

64. West FD, Roche-Rios MI, Abraham S, et al. KIT ligand and bone morphogenetic protein signaling enhances human embryonic stem cell to germ-like cell differentiation. Hum Reprod. 2010;25(1):168-178.

65. Richards M, Fong CY, Bongso A. Comparative evaluation of different in vitro systems that stimulate germ cell differentiation in human embryonic stem cells. Fertil Steril. 2010;93(3):986-994. 
66. Medrano JV, Ramathal C, Nguyen HN, Simon C, Reijo Pera RA. Divergent RNA-binding proteins, DAZL and VASA, induce meiotic progression in human germ cells derived in vitro. Stem Cells. 2012; 30(3):441-451.

67. Eguizabal C, Montserrat N, Vassena R, et al. Complete meiosis from human induced pluripotent stem cells. Stem Cells. 2011;29(8): 1186-1195.

68. Cheng X, Chen S, Yu X, Zheng P, Wang H. BMP15 gene is activated during human amniotic fluid stem cell differentiation into oocyte-like cells. DNA Cell Biol. 2012;31(7):1198-1204.

69. Danner S, Kajahn J, Geismann C, Klink E, Kruse C. Derivation of oocyte-like cells from a clonal pancreatic stem cell line. Mol Hum Reprod. 2007;13(1):11-20.

70. Dyce PW, Wen L, Li J. In vitro germline potential of stem cells derived from fetal porcine skin. Nat Cell Biol. 2006;8(4):384-390.

71. Dyce PW, Shen W, Huynh E, et al. Analysis of oocyte-like cells differentiated from porcine fetal skin-derived stem cells. Stem Cells Dev. 2011;20(5):809-819.

72. El Hajj N, HaafT. Epigenetic disturbances in in vitro cultured gametes and embryos: implications for human assisted reproduction. Fertil Steril. 2013;99(3):632-641.

73. Wang N, Le F, Zhan QT, et al. Effects of in vitro maturation on histone acetylation in metaphase II oocytes and early cleavage embryos. Obstet Gynecol Int. 2010;2010:989278.

74. Yoshida H, Abe H, Arima T. Quality evaluation of IVM embryo and imprinting genes of IVM babies. J Assist Reprod Genet. 2013;30(2): 221-225.

75. Kuhtz J, Romero S, De Vos M, Smitz J, Haaf T, Anckaert E. Human in vitro oocyte maturation is not associated with increased imprinting error rates at LIT1, SNRPN, PEG3 and GTL2. Hum Reprod. 2014;29(9): 1995-2005.

76. Trounson A, Wood C, Kausche A. In vitro maturation and the fertilization and developmental competence of oocytes recovered from untreated polycystic ovarian patients. Fertil Steril. 1994;62(2):353-362.

77. Guzman L, Ortega-Hrepich C, Polyzos NP, et al. A prediction model to select PCOS patients suitable for IVM treatment based on antiMullerian hormone and antral follicle count. Hum Reprod. 2013;28(5): 1261-1266.

78. Roesner S, Von Wolff M, Eberhardt I, Beuter-Winkler P, Toth B, Strowitzki T. In vitro maturation: a five-year experience. Acta Obstet Gynecol Scand. 2012;91(1):22-27.

79. Li Y, Feng HL, Cao YJ, et al. Confocal microscopic analysis of the spindle and chromosome configurations of human oocytes matured in vitro. Fertil Steril. 2006;85(4):827-832.

80. Nicholas CR, Haston KM, Grewall AK, Longacre TA, Reijo Pera RA. Transplantation directs oocyte maturation from embryonic stem cells and provides a therapeutic strategy for female infertility. Hum Mol Genet. 2009;18(22):4376-4389.
81. Hayama T, Yamaguchi T, Kato-Itoh M, et al. Generation of mouse functional oocytes in rat by xeno-ectopic transplantation of primordial germ cells. Biol Reprod. 2014;91(4):89

82. Bukovsky A. Ovarian stem cell niche and follicular renewal in mammals. Anat Rec (Hoboken). 2011;294(8):1284-1306.

83. Woad KJ, Watkins WJ, Prendergast D, Shelling AN. The genetic basis of premature ovarian failure. Aust N ZJ Obstet Gynaecol. 2006;46(3): 242-244.

84. Swerdlow AJ, Cooke R, Bates A, et al; England and Wales Hodgkin Lymphoma Follow-up Group. Risk of premature menopause after treatment for Hodgkin's lymphoma. J Natl Cancer Inst. 2014; 106(9).

85. Hoekman EJ, Smit VT, Fleming TP, Louwe LA, Fleuren GJ, Hilders CG. Searching for metastases in ovarian tissue before autotransplantation: a tailor-made approach. Fertil Steril. 2015;103(2):469-477.

86. Gonzalez R, Griparic L, Vargas V, et al. A putative mesenchymal stem cells population isolated from adult human testes. Biochem Biophys Res Commun. 2009;385(4):570-575.

87. Abd-Allah SH, Shalaby SM, Pasha HF, et al. Mechanistic action of mesenchymal stem cell injection in the treatment of chemically induced ovarian failure in rabbits. Cytotherapy. 2013;15(1):64-75.

88. Kilic S, Pinarli F, Ozogul C, Tasdemir N, Naz Sarac G, Delibasi T. Protection from cyclophosphamide-induced ovarian damage with bone marrow-derived mesenchymal stem cells during puberty. Gynecol Endocrinol. 2014;30(2):135-140.

89. Liu T, Huang Y, Guo L, Cheng W, Zou G. CD44+/CD105+ human amniotic fluid mesenchymal stem cells survive and proliferate in the ovary long-term in a mouse model of chemotherapy-induced premature ovarian failure. Int J Med Sci. 2012;9(7):592-602.

90. Lai D, Wang F, Chen Y, Wang L, Wang Y, Cheng W. Human amniotic fluid stem cells have a potential to recover ovarian function in mice with chemotherapy-induced sterility. BMC Dev Biol. 2013;13:34

91. Wang F, Wang L, Yao X, Lai D, Guo L. Human amniotic epithelial cells can differentiate into granulosa cells and restore folliculogenesis in a mouse model of chemotherapy-induced premature ovarian failure. Stem Cell Res Ther. 2013;4(5):124.

92. Wang S, Yu L, Sun M, et al. The therapeutic potential of umbilical cord mesenchymal stem cells in mice premature ovarian failure. Biomed Res Int. 2013;2013:690491.

93. Sun M, Wang S, Li Y, et al. Adipose-derived stem cells improved mouse ovary function after chemotherapy-induced ovary failure. Stem Cell Res Ther. 2013;4(4):80.

94. Takehara Y, Yabuuchi A, Ezoe K, et al. The restorative effects of adiposederived mesenchymal stem cells on damaged ovarian function. Lab Invest. 2013;93(2):181-193.

95. Stimpfel M, Cerkovnik P, Novakovic S, Maver A, Virant-Klun I. Putative mesenchymal stem cells isolated from adult human ovaries. J Assist Reprod Genet. 2014;31(8):959-974.
Stem Cells and Cloning: Advances and Applications

\section{Publish your work in this journal}

Stem Cells and Cloning: Advances and Applications is an international, peer-reviewed, open access journal. Areas of interest in stem cell research include: Embryonic stem cells; Adult stem cells; Blastocysts; Cordblood stem cells; Stem cell transformation and culture; Therapeutic cloning; Umbilical cord blood and bone marrow cells; Laboratory,

\section{Dovepress}

animal and human therapeutic studies; Philosophical and ethical issues related to stem cell research. This journal is indexed on CAS. The manuscript management system is completely online and includes a quick and fair peer-review system. Visit http://www.dovepress.com/ testimonials.php to read real quotes from published authors. 